\title{
Making it real: oral communication skill development for undergraduates
}

\author{
Michael R. Penn \\ University of Wisconsin-Platteville, Department of Civil and \\ Environmental Engineering, Platteville, WI 53818
}

\section{Introduction}

Effective communication is paramount to being a successful engineer. Historically, employers have rated communication skills as a highly desired attribute of new graduates (Nguyen, 1998; Riemer, 2002), and have rated the skills of new graduates as deficient. Many universities require that students complete a course in public speaking. Such courses give students presentation experience, typically in a traditional format where the speaker is standing in front of a seated audience. Many engineering professors require students to make oral presentations in courses, often upper-level design courses, in a similar format. This format simulates a public meeting, a particular setting in which practicing engineers (especially civil and environmental engineers) may have the professional responsibility to perform. However, this responsibility is usually given to experienced engineers and project managers, not recent graduates. The oral communication setting in which entry-level engineers are most often placed is that of a business meeting, seated around a conference table. Key differences from the public meeting are that the audience size is much smaller (e.g., 2 to 10 participants), and that the speaker remains seated surrounded by the audience. These differences are significant and impact the approach that a presenter should take to ensure effective communication. A classroom exercise was developed to provide students with experience in this setting.

\section{The Assignment}

An assignment was developed to provide students with an alternative oral communication setting for an upper-level engineering course, CEE 4330 Solid and Hazardous Waste Management at the University of Wisconsin-Platteville. Enrollment is the course varies from approximately 10 to 25 students. The scenario given to the students is a conference meeting which has been called by the Vice-President of a consulting company to investigate new markets for engineering services--remediation strategies for contaminated sites are to be evaluated and discussed. The students act in the role of project managers for the company and are required to research and prepare a presentation on a particular remediation strategy.

\section{The Setting}

A conference room is reserved for the presentations, during either a 2-hour lab period or other time period outside of lecture. The room is ideal in that its sole purpose is for meetings, the 
furnishings and decorations are similar to those of a typical corporate or municipal conference room. It is a room in which students would rarely, if ever, be in attendance. Students are seated around the table and sequentially present their findings while remaining seated. Projected presentations (e.g., Powerpoint) are not allowed. While this technique certainly has the potential to be very effective, and is routinely utilized in the professional setting, students typically gain experience with this tool in other courses requiring oral presentations. This also removes a "crutch" upon which students often rely, focusing their attention while speaking to the screen, rather than to the audience. Furthermore, Lang et al. (1999) suggest that verbal presentation skills are more important than multimedia presentation skills.

\section{Logistics}

The number of meeting participants is limited by the seating capacity of the conference table. Larger conference rooms are available on campus, but it is the author's opinion and experience that a group size of approximately 4 to 8 students is ideal. Smaller groups do not present the challenges of maintaining eye contact and keeping all participants engaged. Larger groups dilute the experience, leading to a distracted and dispersed audience. Furthermore, in order to keep the total meeting time reasonable (1 to 2 hours), a larger number of participants requires individual presentations of shorter duration which inherently limits technical rigor.

Student teams are selected (randomly by instructor or by student preference) to research a remediation strategy from a list of appropriate technologies generated by the instructor. Teams are required to prepare a research summary in outline format. Each member of the team presents the findings at a separate meeting. For example, if there are 18 students enrolled, six teams of three students would be formed. Three separate conferences of six students would be held, whereby one student from each of the six teams presents the team findings, and each student gains exposure to all of the six remediation strategies in a meeting. Fifty percent of the assignment grade is based on the individual presentation skills, 25\% is based on the research outline, and the remaining $25 \%$ is based on group peer evaluation of quality and quantity of individual effort toward developing the research outline.

The research outline includes:

- Introduction of the technology,

- History of the technology,

- Comparison to other approaches,

- Technical details,

- Applicability,

- Advantages/disadvantages, and

- Costs.

Individual presentations are evaluated for the following:

- Clear speech and enunciation,

- Professional vocabulary,

- Eye contact, 
- Speaking volume,

- Enthusiasm/attitude/tone, and

- Composure and posture.

\section{Student Response}

Student response to the exercise has been overwhelmingly positive. A summary of student survey responses is included in Table 1.

\section{Lessons Learned}

Having performed the exercise for three consecutive years, the following modifications have been made based on student responses and instructor observations.

- The instructor sits behind, or "off to the side" of the conference table. This minimizes the student tendency to focus their attention on the instructor rather than their peers.

- A dress code requirement has been eliminated to allow the students to be more comfortable.

- Speakers are allowed to use the research outlines as a guide during presentations, however meeting participants are not provided outlines until after the presentations are completed. This requires the audience to be attentive, rather than merely "reading along" with the outline. This provides a much greater opportunity for the speaker to utilize eye contact and body language.

- Speakers may provide paper copies of up to three diagrams to the meeting participants as visual aids.

- Students are encouraged to be professional without being overly formal.

- After the presentations are completed, students are asked to comment (without specifically identifying individuals) on observed strengths and weaknesses of the presentations in general.

- Videotaping the presentations gives the students an opportunity to see and hear how they perform in this setting (Polack-Wahl, 2000). 


\begin{tabular}{|c|c|c|c|c|c|}
\hline & $\begin{array}{l}\text { Strongly } \\
\text { Agree }\end{array}$ & Agree & Maybe & Disagree & $\begin{array}{l}\text { Strongly } \\
\text { Disagree }\end{array}$ \\
\hline $\begin{array}{l}\text { As a result of the meeting, I have a better understand- } \\
\text { ing of the dynamics of professional meetings }\end{array}$ & 7 & 17 & 3 & & \\
\hline $\begin{array}{l}\text { As a result of the meeting, I feel better prepared to } \\
\text { present in an actual professional meeting situation }\end{array}$ & 7 & 18 & 1 & & \\
\hline $\begin{array}{l}\text { I was more nervous at the conference table than I } \\
\text { thought I would be }\end{array}$ & 5 & 7 & 6 & 8 & 1 \\
\hline $\begin{array}{l}\text { Speaking at the table was less stressful than speaking } \\
\text { in front of the entire class }\end{array}$ & 8 & 10 & 7 & 2 & \\
\hline $\begin{array}{l}\text { Role-playing as a professional significantly hindered } \\
\text { my ability to give the presentation }\end{array}$ & & 1 & 5 & 18 & 3 \\
\hline Maintaining eye contact was very challenging & 2 & 1 & 11 & 13 & \\
\hline $\begin{array}{l}\text { The other presentations were interesting, and I } \\
\text { learned more about environmental engineering from } \\
\text { them }\end{array}$ & 5 & 15 & 4 & 3 & \\
\hline $\begin{array}{l}\text { The expectations of the students (by the instructor) } \\
\text { for this assignment were clearly understood }\end{array}$ & 1 & 17 & 9 & & \\
\hline $\begin{array}{l}\text { I would strongly recommend including meetings in } \\
\text { future classes }\end{array}$ & 13 & 14 & & & \\
\hline
\end{tabular}

Table 1. Summary of student survey responses from 2006 and 2007.

\section{Conclusions}

An alternative oral communication exercise has been developed to simulate a common professional setting for both entry-level and experienced engineers. Student response to the exercise has been overwhelmingly positive. The time commitment for both students and faculty is not excessive. In addition to oral communication skill development, students gain exposure to additional material not covered in lecture. Students are provided with the research summaries to use as study guides for exams. Furthermore, this information is presented by the students to the students. 


\section{References}

Lang, J.D., Cruse, S., McVey, F.D \& McMasters, J. (1999). Industry Expectations of New Engineers: A Survey to Assist Curriculum Designers. Journal of Engineering Education, January, 43-51.

Polack-Wahl, J.A. (2000). It is time to stand up and communicate. Proceedings of the 30th ASEE/IEEE Frontiers in Education Conference, Kansas City, USA, F1G16-F1G21.

Nguyen, D.Q. (1998). The Essential Skills and Attributes of an Engineer: A Comparative Study of Academics, Industry Personnel and Engineering Students. Global Journal of Engineering Education, 2(1), 65-75.

Riemer, M.J. (2002). English and Communication Skills for the Global Engineer. Global Journal of Engineering Education, 6(1), 91-100.

MICHAEL R. PENN is a Professor of Civil and Environmental Engineering with BS and MS degrees from the University of Michigan, and a PhD from Michigan Technological University. Teaching interests include utilizing nontraditional approaches to engage students both in and out of the classroom. 